\title{
İslâm Devletinin Diğer İslâm Devletiyle Savaşmasının Meşru ve Gayri Meşru Olduğu Durumlar
} \begin{abstract}
Ahmet ÖZDEMIR ${ }^{1}$
Öz

İslâm devletlerinin aralarındaki ilişkilerin barışa dayalı ve kardeşlik hukuku içinde olması gerekir. Ancak iç ve dış etkenlerle Müslümanların birbirleri ile ilişkilerin bozulduğu ve çatışmaların yaşandığı da tarihî bir gerçekliktir. Bu çalışmada bir İslâm devletinin kendisi ile aynı inancı paylaşan diğer İslâm devleti ile hangi durumlarda savaşabileceği ve hangi durumlarda savaşamayacağı hususunun açılığa kavuşturulması hedeflenmektedir. Ülkenin sınırlarını her türlü saldırıya karşı korumak, dünyadaki sömürgeci ve emperyalist güçlerin planlarını bozmak, haksız saldırıya uğrayan İslâm devletinin yanında yer alıp ona zor anında destek olmak, Müslümanların birlikteliğini ve ümmet şuurunu bozan ve müminler arasında fitne ve fesada yol açanları durdurmak amacıyla yapılacak savaşlar dinin genel ilkelerine aykırılık taşımadığı için meşru savaşlardır. Bu gayelere ulaşmak için İslâm devletinin diğer İslâm devletine karşı savaş dâhil olmak üzere zamanın şartlarına en uygun metotlarla mücadele içinde olması onun hakkıdır. İslâm devletinin meşru bir gerekçeye dayalı olmaksızın Müslüman toplumlara savaş açması ise hiçbir zaman meşru olmayacaktır. Mezhep taassubu ile hareket edip farklı mezhep mensuplarını ortadan kaldırmak, diğer İslâm devletlerinin zenginliklerini sömürüp hükümranlık alanını genişletmek, dünyadaki sömürgeci ve emperyalist güçlerin amaçlarına hizmet etmek gibi meşru zemine oturmayan gayelerle Müslümanların yaşadıkları ülkelere saldırılar düzenlemek gayri meşrudur. Meşru olmayan sebeplerle savaş ilan edip Müslümanların ölmesine sebep olanlar büyük bir sorumluluk taşımaktadırlar.
\end{abstract}

Anahtar Kelimeler: Fı1kıh, İslâm devleti, Savaş, Cihad, Sömürgecilik

\section{Situations Where Conflicts between Islamic States are Legitimate and Illegitimate}

\section{Abstract}

The relations between Islamic states should be based on the law of peace and fraternity. However, the historical reality is that internal and external factors as well as relationship between Muslims are being destroyed and conflicts arise. The aim of the study is to clarify the situations when the Islamic state can and cannot struggle with other Islamic states. The wars are considered to be legitimate and do not contradict their principles as they are held to protect the borders of the country against all kinds of attacks, to disrupt the plans of the colonial and imperialist powers in the world, to support the unfairly attacked Islamic state, and to stop those who cause mischief and mischief among the believers and stop the unity of Muslims and unity. In order to achieve it the Islamic state has right to fight with another Islamic state struggles using methods that are most suitable for the conditions and time. It will be illegitimate for the Islamic state to start a war against other Muslim societies without any legitimate reason. It is illegal to attack countries where Muslims live by committing actions that have no legal basis, such as acting through sectarian mourning and destroying members of various sects, exploiting the wealth of other Islamic states and expanding the zone of sovereignty, as well as serving the purposes of the colonial and imperialist powers in the world. Those who declared war for unjustified reasons and killed Muslims bear great responsibility.

Key Words: F1qh, Islamic state, war, jihad, colonialism

\section{Atıf İçin / Please Cite As:}

Özdemir, A. (2020). İslâm devletinin diğer İslâm devletiyle savaşmasının meşru ve gayri meşru olduğu durumlar. Manas Sosyal Arastirmalar Dergisi, 9(2), 1157-1167.

Geliş Tarihi / Received Date: 21.03.2019

Kabul Tarihi / Accepted Date: 03.06.2019

\footnotetext{
1 Doç. Dr. - Kastamonu Üniversitesi İlahiyat Fakültesi, aozdemir@kastamonu.edu.tr ORCID: 0000-000a2-5273-1601
} 


\section{Giriş}

Başlangıçta tek bir İslâm devleti çatısı altında olan Müslümanlar Endülüs Emevi Devletinin kurulması ile fiilen ikiye bölünmüş, ilerleyen yüzyıllarda bu bölünme devam ederek dünyada birçok İslâm devleti ortaya çıkmıştır. Dünyadaki birden fazla İslâm devletinin birbirleri ile münasebetlerinin barış, dostluk ve kardeşlik üzere kurulması olması gereken ve ideal olandır. Müminlerin kardeş olduğunu beyan eden nasların toplum hayatında tatbik edilmesi durumunda İslâm devletlerinin birbirleri ile savaş yapması hiçbir zaman gündeme gelmeyecektir. Ancak yöneticilerin bilgisizliği, düşmanların kışkırtmaları, ulemanın gereken uyarıları yapmamaları, nefsanî arzuların ve bağnazlı̆ıı hâkim gelmesi gibi etkenlerle tarih boyunca Müslüman toplumlar arasında çatışmalar yaşanmış ve günümüzde de yaşanmaya devam etmektedir.

Müslümanlar asr-1 saadet devrinden sonraki yüzyllarda dünyada birden fazla devlete sahip olmaya başladıkları için naslarda doğrudan doğruya iki İslâm devleti arasındaki ilişki hakkında bilgi bulmak mümkün olmamakla birlikte, Müslümanların fert olarak birbirlerine karşı vazife ve sorumlulukları, İslâm dininin genel hedefleri ve hikmetü't-teşrî kapsamında yer alan bilgilerden hareketle araştırılan mevzu hakkında sonuçlara ulaşmak mümkündür. İslâm devletleri arasında kardeşlik ve yardımlaşmanın hâkim olması ana esas olarak belirlenmelidir. Ancak uluslararası ilişkilerin birçok etkene ve denkleme dayalı değişken bir yapısının olması, aynı dine mensup devletleri bile zaman zaman karşı karşıya getirebilmektedir.

Müslümanlar, şahit oldukları zulüm ve haksızlıklar karşısında ellerinden geldiği ölçüde mücadele etmekle sorumludur. Bu sebeple İslâm devleti, kendisine ya da mazlum bir devlete karşı yapılan saldırıya kimden gelirse gelsin karşı koymakla ve İslâm ümmetinin menfaatine aykııı davrananları durdurmakla mükelleftir. Bu ve benzeri durumlar barış ve diplomasi yoluyla çözülememesi durumunda savaş yoluna başvurmak meşru olacaktır. Buna karşıllk, bir İslâm devletinin başka bir İslâm devletiyle toprak, mal, mülk ve hükümranlık elde etmek amaciyla savaşması meşru olmayacaktır.

Araştırılan mevzu, İslâm devletlerinin kendi aralarındaki savaşın hükmünü tespit etmek olduğu için Müslüman olmayanlarla ilişkiler ve onlarla savaşı meşru kılan durumlar burada ele alınmamaktadır. Müslüman ile gayrimüslim toplumlar arasındaki münasebet konusu, tarihî süreçte ortaya çıkan fiilî durum ile günümüzde uygulanabilecek metodun ayrı ayrı incelenmesini gerektiren geniş bir muhtevaya sahiptir. Devlete isyan ve bağy suçu kapsamına giren suçlularla mücadele, devletlerarası nitelik taşımayıp devletin iç işleri kapsamında yer alması daha isabetli görüldüğ için bu çalışmada yer almamaktadır. Nitekim devletin iç isyanları bastırma amacıyla yaptı̆̆ mücadelenin savaş olarak değerlendirilmesi ihtilaf edilen bir husustur (Doğan, 2018, s. 113).

\section{A-İ̀slâm Devletinin Başka Bir İslâm Devletine Karşı Savaşmasını Meşru Kılan Sebepler}

Bir İslâm devletinin diğer İslâm devleti ile ilişkilerinde barış ve kardeşliğin esas olması gerektiğinden dolayı birbirleri ile savaş yapmalarının meşru olmaması gerekir. Ancak devletlerden birisinin yapacağı olumsuz ve zarar verici davranışlar başka tedbirlerle önlenemiyorsa savaş meşru hale gelecektir. Buna göre; İslâm devletinin, kendi ülkesinin sınırlarını korumak, sömürgeci ve emperyalist devletlerin herhangi bir İslâm devletini kullanarak kurdukları hileleri bertaraf etmek, saldırıya uğrayan Müslümanların yanında yer alıp zalimi durdurmak, ülkesi için tehdit unsuru olan terör faaliyetlerini yok etmek ve ümmet birlikteliğini temin edebilmek amacıyla savaş yapması meşru olacaktır. Ancak savaş yöntemine diğer tüm çözüm yolları netice vermemesi durumunda başvurulabilecektir.

\section{1-Ülke Sınırlarını Korumak}

Ülke, bir milletin üzerinde yaşadığı ve devletin hükümranlık alanını belirleyen deniz, hava ve kara sınırları ifade etmektedir. Ülke, bir devletin faaliyet alanını ifade eder, orada fiilî kontrol ve hâkimiyetini tesis eder (Özel, 1981, s. 110). Bir aile için evin mahremiyetinin korunması nasıl önemli ise bir millet için de vatanın sınırlarının korunması son derece önemlidir. İslâm devleti kendisine düşmanca davranan kim olursa olsun ona karşı mücadele edip ülkenin sınırlarını koruma hakkına sahiptir. Bu saldırının başka bir İslâm devletinden gelmesi durumunda da elinden gelen tüm imkânları kullanarak karşı koyması meşru olacaktır. Bu hükmün temelinde meşru müdafaa hakkı gelmektedir. Gerek fert olarak gerekse toplum olarak haksız bir saldırı ile karşı karşıya kalanların kendilerini savunmaları hukukun tanıdığı bir hak ve yetkidir.

Bir ülkede yaşayan Müslümanların yaşadığı topraklara haksız saldırı ister gayrimüslimlerden isterse de aynı inancı paylaştığı insanlardan gelsin bu durumda olan devletler saldırıya karşı koymak hakkına sahiptirler. Ayet-i Kerime'de "Kim zulme uğradıktan sonra hakkını alırsa, artık onlara yapılacak bir şey 
yoktur." (Kur'an-1 Kerim 42: 41) buyrularak hakk1 yenen insanların haklarını talep etme yetkilerinin olduğuna işaret edilmektedir. Ayette, delalet ettiği tüm unsurları sınırsız olarak içine alan âmm lafizlardan olan "bulunması fert ya da toplum olarak herkesin karşılaştı̆̆ zulme engel olma hakkı olduğunu göstermektedir. Vatan toprağına yapılan haksız saldırılar zulüm kapsamında olacağı için ayetin umumî manasına dâhildir. Resûlullah'ın "Bize silah doğrultan bizden değildir." (Müslim, İman: 293) ve "Müslümanın kanı, malı ve 1rzı bütün Müslümanlara haramdır." (Ebû Dâvûd, Edeb: 4882) beyanları da Müslümanların toprağını ele geçirmek için saldırıya geçenlerin bu davranışlarının meşruiyetinin olamayacağını açı bir şekilde göstermenin yanında onlarla mücadeleye de zımnen izin vermektedir. Bütün bu hususlara ilave olarak, şahsî mülkiyete ait değerleri korumak ve gerekirse ölüm pahasina bu uğurda mücadele etmek Hz. Peygamber'in "Malı uğrunda öldürülen şehittir." (Buhârî, Mezâlim: 2348) beyanı ile meşru olduğuna göre, tüm millete ait olan ülkenin savunulması evleviyetle meşru olacaktır.

Meşru müdafaa hakk1, insanlığın fitraten kabul edeceği tabiî bir hak olduğu için uluslararası anlaşmalarda da bu husus kabul edilmiştir. Birleşmiş Milletler anlaşmasının 2. maddesi her milletin toprak bütünlügüne sayg1 göstermeyi devletlerin uyması gereken kural olarak belirlemiştir. "Devletlerin uluslararası ilişkilerde birbirlerinin toprak bütünlüğü ve siyasal bağımsızlıklarına saygı göstermeleri gerekir." Birleşmiş Milletler anlaşmasının 51. Maddesi kuvvet kullanma yasağının tek istisnası olarak meşru müdafaayı kabul etmektedir. Ancak bu hakkın kullanılabilmesi de, birleşmiş milletlerin ortak emniyet sisteminin işlemediği durumlarda söz konusu olmaktadır. Maddede yer alan "münferit veya müşterek meşru müdafaa" ifadesi yer aldığı için devletin kendisini savunurken başka devletlerden yardım alması mümkündür. Bunun sebebi saldırgan devlet esasında sadece saldırdığı devlete değil, bütün devletlere karşı taahhüdünü ihlal etmiş olmasıdır. Bu sebeple iki devlet arasında daha öncesinde ortak savunma gibi bir anlaşma olmasa da müşterek müdafaaya başvurabilirler (Belik, 1956, s. 47-48).

Bir devletin başka devlete saldırısı devletin topraklarını ilhak şeklinde olabildiği gibi devlet destekli terör şeklinde de kendisini gösterebilmektedir. Terör faaliyetleri birden fazla ülkenin topraklarını ve insanlarını hedef alması ya da bir devletin veya uluslararası örgütün siyasî mekanizmalarını etkilemeyi amaçlaması durumunda terör, uluslararası bir boyut kazanmakta (Altuğ, 1995, s. 14) ve bir devletin başka devletlerin egemenliğini, ülke bütünlüğünü, siyasî bağımsızlı̆ını hedef alan terör örgütlenmelerine doğrudan veya dolaylı destek vermek uluslararası hukuk açısından o devlete yapılmış bir saldırı sayılmaktadır. (Örgün, 2001, s. 68) Herhangi bir devlet, stratejik amaçları için terörizmi kullanıyorsa, bu tür faaliyetlere lojistik destek sağliyorsa, teröristleri koruyorsa, terörist örgütlerle yeteri kadar mücadele etmiyorsa devlet destekli terör söz konusu olur (Öztürk, 2000, s. 140). Devletlerarası münasebetlere etkisi sebebiyle devlet destekli terör uluslararası terör kavramının içinde yer almaktadır. Birleşmiş Milletler Genel Kurulunun 1970 tarihli devletler hukuku ilkeleri hakkındaki bildirisi de devletlere terörü desteklememe sorumluluğu yüklemektedir. "Her devletin diğer devletteki bir savaşı veya terörist hareketleri örgütlemekten, tahrik etmekten ve onlara yardım etmekten veya bu hareketlere katılmaksızın kendi ülkesinde böyle hareketlerin yapılmasına yönelik faaliyetlere... göz yummaktan kaçınma görevi vardır." (Arslan, 1996, s. 179).

Terörizm bugün uluslararası siyasetin bir parçası olarak da kullanılmaktadır (A. Özdemir, 2017, s. 44). Sıcak savaşların sona ermesi ve uluslararası arenada saldırı amaçlı savaşın meşrû kabul edilmemesi sonucunda bazı devletler çıkarlarını gerçekleştirmek için terörizmi destekleme yoluna gitmektedir. İslâm hukuku bakımından uluslararası ilişkilerde uyulması gereken en önemli prensiplerden birisi de teröre karşı olmaktır. İslâm dini, haksızlığa, haddi aşmaya ve zulme asla izin vermez. (Kur'an-1 Kerim 16: 90) Savaşta bile muharip olmayan (Serahsî, 1989, X, 4-6) kadınların, çocukların, yaşlıların, din adamlarının öldürülmesine cevaz vermeyen (İbn Kudâme, 1992, XIII, 66) İslâm dininin terörü desteklemesi mümkün değildir. Hedefin meşrû olması yetmez, o hedefe ulaşırken izlenen metodun da meşrû olması gerekir (A. Özdemir, 2017, s. 45). Terörle ulaşılabilecek hiçbir meşrû hedef olamaz. "Müslüman, dilinden ve elinden diğer Müslümanların selamette olduğu kimsedir..." (Nesâî, İman: 4996). Bir İslâm devleti kendi çıarları için ülkesinde diğer devletler için ciddi tehdit oluşturan terör örgütlerinin varllğına izin veriyorsa terör saldırısı altındaki İslâm devletlerinin bununla mücadele etmesi meşru hakları olacaktır. Bu amaçla yapılan mücadele ülke sınırlarını koruma ve vatandaşların can-mal güvenliğini sağlama kapsamındadır.

Bir devletin sınırları içinde başka devletlere saldıran terör örgütünün mevcut olmasının iki sebebi olabilir. Birincisi, devletin bilerek ve isteyerek terör örgütüne destek olmasıdır. İkincisi ise, devletin terör örgütü ile yeterince mücadele edebilme iktidarının olmamasıdır. Bir devletin bilerek teröre destek vermesi başlı başına bir suç olduğu için onunla mücadele tabiî olarak meşru olacaktır. Terör örgütleri ile 
mücadeleye gücü ve iktidarı yetmediği için engel olamaması durumunda o devletin bizzat kendisinin tehdit altındaki ülkelerden destek alarak mücadele etme sorumluluğu söz konusu olacaktır. Sonuç olarak her iki halde de saldırı altındaki devletin terör örgütüne karşı gerekli olması durumunda sınır ötesi harekât yapması meşru olacaktır.

\section{2-Dünyadaki Sömürgeci ve Emperyalist Güçlerin Planlarını Bozmak}

Sömürgecilik, kendisine ait olmayan toprakları ve ülkeleri, genellikle güç ve şiddet kullanarak ekonomik çıkar sağlamak amacıyla işgal ettikten sonra buralardaki yeraltı yerüstü zenginliklerini kendi menfaati için kullanma olarak tanımlanmaktadır. (Seyyar, 2007, s. 955) Emperyalizm ise, bir milletin siyasî ve iktisadî gücünün taşması veya taşma eğilimi göstermesi olarak tanımlanabilir (Ülken, 1969, s. 95). Sömürgecilik, emperyalizmin farklı bir türüdür. Günümüzde dünyada işgale dayanan sömürgecilik anlayışı yerini çağdaş sömürme yöntemlerine bırakmıştır. Kültürel, ekonomik ve yapısal emperyalizm doğrudan açık siyasî kontrolün olmadığı daha sinsi ilişki biçimlerini ifade etmektedir. (Evans ve Newnham, 2007, s. 202, 569)

İslâm devletlerinin kararlarında bağımsız olup milletin ve kutsal değerlerin aleyhine kararlar almaması arzu edilen bir durum olmakla birlikte, tarih boyunca zaman zaman şahsî çıkar ve küçük hesaplarla devletlerini yöneten hükümdar ve yöneticiler de bulunmuştur. Bir İslâm devleti, uluslararası emperyalist güçlerin ve devletlerin çıkarlarına hizmet edip, diğer Müslüman toplumların aleyhine tehdit unsurları taşıyorsa, ona karşı mücadele hakkı bulunmalıdır. Mücadelenin başlangıçta diplomatik araçlar kullanılarak yapılması tabiîdir. Ancak sonuç vermemesi halinde, güç kullanarak emperyalist güçlerin plan ve hilelerini bozmak meşru olacaktır.

Müslümanlara açıktan düşmanlık besleyenlerle ittifak kurulamayacağı gibi düşmana arka çıkan ve destek olanlarla da ittifak kurmak nehyedilmiştir (Kur'an-1 Kerim 60: 9). "Müminler, müminleri bırakıp da kâfirleri dost edinmesin. Kim bunu yaparsa, artık onun Allah nezdinde hiçbir değeri yoktur. Ancak kâfirlerden gelebilecek bir tehlikeden sakınmanız başkadır. Allah, kendisine karşı (gelmekten) sizi sakındırıyor. Dönüş yalnız Allah'adır." (Kur'an-1 Kerim 3: 28) ayeti gayrimüslim toplumlarla ilişkilerde uyulması gereken temel ölçüyü sunmaktadır. Bir mümin topluluğun aynı inancı paylaşan kardeşlerini bırakıp kâfirlerle dostluk kurması doğru değildir. Bununla birlikte gayrimüslim toplumlardan gelebilecek zararlardan emin olmak amacıyla belirli anlaşmalar ve işbirlikleri yapmak ise mümkündür. Ancak bu anlaşmaların başkalarının haklarını ve hukukunu ihlal etmemesi, Müslümanların zararına yol açmaması gerekir.

İslâm devletleri arasında fizikî birlikteliği bozma amacıyla askerî üstler ve özerk bölgeler inşa etmek, yeraltı ve yer üstü zenginlikleri süresiz ve sınırsız dış güçlerin hâkimiyetine bırakmak, ödenmesi imkânsız büyük borçlar ile milletin geleceğini ipotek altına almak sömürgeci devletlerin başvurduğu planlardandır. Bir İslâm devleti yönetiminin bu ve benzeri planlara destek vermesi durumunda onunla Müslümanların çıkarlarını koruma adına mücadele etmek meşru olacaktır. Gayrimüslime tâbî olmayı haram kılan İslâm dini, sömürgeci işgalcilerle cihad etmeyi, onları İslâm ülkesinden kovmay1 ve yaptıkları planları bozmayı istemektedir. Bu mücadeleyi yaparken sömürgecinin (Udeh, 1988, s. 126) ve onlarla işbirliği içinde olanların malı ve canı Müslümanlara mubahtır.

Sömürgeci güçlere teslimiyet içindeki yöneticileri uyarmak ve yapılan yaşlıktan vazgeçmelerini sağlamak öncelikli olarak o devletin vatandaşlarına düşmektedir. Konunun sadece ülkenin iç işleri ile ilgili sınırlı kalması durumunda diğer İslâm devletlerinin müdahalesi fayda yerine zararlı olacaktır. Bu durum İslâm devletlerinin birbirleri ile ilişkisinin bozulmasına hatta Müslümanlar arasında meşru olmayan bir savaşın başlamasına sebep olabilecektir. Ancak bir İslâm devletinin emperyalist güçlerin istekleri doğrultusunda aldığı kararların diğer devletlere ve İslâm ümmetinin ortak çıarlarına açı zarar vermesi durumunda o devlete karşı her türlü mücadele meşruiyet kazanacaktır.

\section{3-Başka Bir İslâm Devletine Yapılan Haksız Saldırıları Durdurmak}

İslâm dini Müslümanlara, hiçbir kimseye karşı haksızlık yapmamalarını ve başkalarının haksız uygulamaları karşısında da duyarsız kalmamalarını emretmektedir (A. Özdemir, 2017, s. 40). Müslüman gördüğü kötülügü eliyle düzeltmeli, buna gücü yetmiyorsa dili ile düzeltmeli, buna da gücü yetmiyorsa o davranışı tasvip etmeyip kalbiyle buğzetmelidir (Müslim, İman: 49). Ayrıca zalimlerin zulümlerine engel olunmaması durumunda herkesi kuşatan bir bela ile karşılaşılacağının haber verilmesi (Ebû Dâvûd, Melâhim: 4338) konunun hassasiyetini göstermektedir. 
Bir Müslüman topluluk başkasına karşı haksız yere saldırıyorsa diğer Müslümanların bu olaya kayıtsız kalması düşünülemez. Ayet-i Kerime'de "Eğer müminlerden iki grup birbirleriyle vuruşurlarsa aralarını düzeltin. Şayet biri ötekine saldırırsa, Allah'in buyruğuna dönünceye kadar saldıran tarafla savaşın. Eğer dönerse artık aralarını adaletle düzeltin ve (her işte) adaletli davranın. Şüphesiz ki Allah, âdil davrananları sever." (Kur'an-1 Kerim 49: 9) buyrularak haksız saldırana karşı sslah olmaması durumunda mazlumun yanında yer alarak savaşılmasını Müslümanlara bir görev olarak verilmiş̧ir. "Bir haksızlığa uğradıkları zaman, yardımlaşırlar.” (Kur'an-1 Kerim 42: 39) ayeti de haksızlık yapan gerek içerden gerek dışardan olsun, bütün İslâm devletlerine bu haksızlığa karşı beraberce mücadele etme sorumluluğu vermektedir. Haksız saldırıya cevap verilmesinin gerekli olmasının sebebi zulme kayıtsız kalmayıp haksızlığa engel olmaktır. "Ancak insanlara zulmedenlere ve yeryüzünde haksız yere taşkınlık edenlere ceza vardır. İşte acıklı azap bunlaradır." (Kur'an-1 Kerim 42: 42) ayeti haksız yere saldıran zalimlerin cezayı hak ettiğini beyan etmektedir.

Konu ile ilgili ayetlerin devletlerarası ilişkilere yansımasını şu şekilde belirlemek mümkündür. Bir İslâm devleti başka bir İslâm devleti tarafindan saldırıya uğraması durumunda diğer İslâm devletlerinin bu olaya kayıtsız kalması mümkün değildir. Öncelikle yapılması gereken diplomatik görüşmeler, arabuluculuk faaliyetleri gibi problemi çözme ve tarafları barıştırma amacıyla çaba sarf edilmesidir. Bu çabaların sonuç vermemesi durumunda saldırgan tarafi durduruncaya kadar mazlum toplumun yanında savaşa iştirak etmek diğer Müslümanların görevidir. Saldırıya geçen devlet, hatalı davranışının farkında olup saldırıdan vazgeçmesi durumunda bu topluluk hakkında zulme sapmadan adalete dayalı olarak karar vermek gerekir.

Hz. Peygamber'in "Kişi kardeşine zalim de olsa mazlum da olsa yardım etsin. Kardeşi zalim ise zulümden onu alıkoysun. Böyle yapmak ona yardım etmektir. Kardeşi mazlum durumda ise ona (destekçi olarak) yardım etsin.” (Müslim, Birr ve's-sıla: 6747) beyanı zalim de olsa mazlum da olsa müminlere yardım etme görevi yüklemektedir. Zalim olan din kardeşe yardım, onun dünyevî ve uhrevî cezaya müstahak olmaması için zulmüne engel olma şeklinde gerçekleşirken, mazlum konumunda olan kardeşe yardım, onu desteklemekle sağlanacaktır. Bu destek, onu zulümden kurtarmak amacıyla, gerekli olması durumunda onun yanında savaşarak sağlanacaktır.

Zalime karşı mazlumu Müslümanların birlik olarak topluca savunma ilkesi hayatta tatbik edilmesi durumunda birçok zulüm ortaya çıkmadan sona erecektir. Çünkü bu ilke, haksız saldırı planlayan bir devlet için son derece etkili bir caydırıclık içermektedir. Günümüz dünyasında Müslümanlar arasında savaşların sıkılıkla yaşanmasının nedeni, ayette beyan edilen kurala göre hareket eden bir İslâm câmiasının bulunmamasıdır. Konu ile ilgili ayet (Kur'an-1 Kerim 49:9) mazlumun yanında mücadele etmeyi emrederken, esasında sağladığı caydırıcıllk etkisiyle birçok savaşı daha başlamadan sona erdirmektedir.

\section{4- Ümmet-i Muhammed'in Birliğini Temin Etmek}

Sözlük anlamı itibariyle topluluk, halk, cemaat anlamlarına gelen ümmet kavramını terim olarak, bir din etrafinda birleşen, ortak bir inancı olan insanlardan oluşan topluluk (Ahmed, 1988: VIII,427) olarak tanımlamak mümkündür (İbn Kuteybe, 1973, s. 445). Ümmet kavramı, İslâm toplumunu tanımlayan en kapsamlı kavram olup, aynı gayeyi hedefleyerek bir araya gelmiş insan topluluğunu ifade etmektedir (Durmuş, 2006: 35). Ümmet-i Muhammed denilince, Hz. Muhammed'in peygamberliğine inanıp onun getirdiği esasları benimseyen mü’minler topluluğu kastedilmektedir.

Bir İslâm devleti uyguladığı politikalar ile diğer İslâm devletlerinin birlikteliğine engel oluyorsa, kabile ve hanedan menfaatini her şeyin üstünde tutarak fitne ve bölünmenin başını çekiyorsa, onunla mücadele etmek meşru olacaktır. Bu hükmün temelinde Müslümanların birlik ve beraberliğine vurgu yapan, fitne ve fesadı yasaklayan ayet ve hadisler gelmektedir. "Hep birlikte Allah'ın ipine (İslâm'a) sımsıkı yapışın; parçalanmayın..." (Kur’an-1 Kerim 3: 103). "Kendilerine apaçık deliller geldikten sonra parçalanıp ayrıllğa düssenler gibi olmayın. İşte bunlar için büyük bir azap vardır." (Kur’an-1 Kerim 3: 105). "İkiyüzlüler, kalplerinde fesat bulunanlar, şehirde bozguncu haberler yayanlar, eğer bundan vazgeçmezlerse, and olsun ki, seni onlarla mücadeleye davet ederiz; sonra çevrende az bir zamandan fazla kalamazlar. Hepsi de lânetlenmiş olarak nerede ele geçirilirlerse, yakalanır ve mutlaka öldürülürler.” (Kur’an-1 Kerim 33: 60-61). Resûlullah (s.a.), birçok hadisinde Müslümanlar arasında mevcut olması gereken kardeşlik hukukunun ilke ve esaslarını beyan etmiş (A. Özdemir, 2014, s. 10-89), mü'min topluluğu, parçaları birbirine sıkıca bağlanmış bir binaya benzeterek (Buhârî, Edeb: 6026) ümmet bilincine dikkat çekmiştir. 
Hilafet görevini üstlenen Hz. Ebu Bekir’in zekât vermeme bahanesi arkasına sığınıp fitne çıkaran, Müslümanlanın birlikteliğini bozma çabasında olan kabilelerle yaptığı mücadelesinin ana eksenini ve meşruiyet zeminini Ümmet-i Muhammed'in birlikteliğini temin etme olarak görebiliriz.

Müslümanların siyasî yapı itibariyle tek bir devlet altında toplanma mecburiyetleri olmamakla birlikte, aynı inancı paylaşmanın verdiği sorumlulukla ümmet bilinci içinde hareket etme mecburiyeti bulunmaktadır. İslâm devletlerinin uluslararası ilişkilerde ümmet şuurundan yoksun olarak kararlar alması Müslümanların zayıflamasına, zenginliklerinin sömürülmesine, gayrimüslimlerin baskı ve yaptırımlarına maruz kalmaya sebep olabilmektedir. İslâm devletleri, yaşanılan dünya düzeninin şartlarına uygun ve gerçekleştirilebilir bir birliktelik kurma çabası içinde iken bu çalışmalara engel olan, birlikteliğin kurulmaması için gayret gösteren bir İslâm devletine karşı yaptırımın olması gerekir. Bu yaptırım, diplomasinin verdiği tüm imkânların kullanılmasından başlamakla birlikte, cebrî tehdit ve vazgeçirme yollarına da başvurulabilecektir.

Dünyada inanç, tarih, ülkü birliği gibi çeşitli bağlantılarla birbirine yakın olan devletlerin ortak birliktelikler kurması geçmişte ve günümüzde sıkılıkla başvurulan uygulamalardandır. İslâm devletleri de aynı inanç birlikteliği temelinde bir birlik ve ortaklık kurma çabasında iken bir İslâm devletinin kendince gerekçeler ileri sürerek bu birlikteliğe dâhil olmaması ona karşı mücadeleyi meşru kılmayacaktır. Çünkü siyasî ve sosyal yapısı itibariyle buna hazır olmayabilir veya iç işlerinde olumsuz sonuçlar doğma riski bulunabilir. Bu devlet kendi politikası ve kararı ile baş başa bırakılır. Ona karşı yaptırım uygulanmaz. Ancak bir devlet, kendisi İslâm devletleri arasında kurulmaya çalısıllan birlikteliğe katılmadığ gibi, böyle bir ortaklık kurulmaması için çaba gösteriyorsa, çeşitli vaatler ile kendisine yakın gördüğü devletleri birliğe katılmaktan vazgeçmeye çağırıyorsa onunla mücadele meşruiyet zemini bulacaktır. Çünkü bu davranışın altında suiniyet bulunduğu gibi, İslâm ümmetinin çıkarlarına ve menfaatine alenen karşı durma söz konusudur. Bu şekilde hareket etmenin muhtemel sebeplerinden birisi dünyada güç dengesinin aleyhlerine değişmesinden endişe eden uluslararası sömürgeci güçlerin istek ve arzularına boyun eğmektir. Müslüman olmayanların Müslümanları birlikten vazgeçmeye çağırması, tam ters bir etki ile Müslümanların daha sıkı ilişkiler kurmasına yol açabilecektir. Bu durumun farkında olan uluslararası güçler hedeflerine bir İslâm devletini kullanarak ulaşmak isteyebilirler. Bu ve benzeri gayri meşru talepler doğrultusunda dış politikasını belirleyen bir devletin çeşitli müeyyideler ile karşılaşması tabiîdir.

$\mathrm{Bu}$ gerekçelere dayalı olarak, Müslümanların işbirliği yapmasına engel olmaya çalışan fitne hareketlerine karşı, inananlar arasında birliktelik kurma çabasında olanların mevcut şartlara uygun her türlü mücadeleyi yapmaları meşru olacaktır. Birlikteliği bozmaya çalışan devleti bu politikasından vazgeçmesi için izlenen tüm yolların sonuçsuz kalması durumunda savaş alternatifi de gündeme gelebilecektir.

\section{B- İslâm Devletinin Başka Bir İslâm Devletine Karşı Savaşması Meşru Olmayan Durumlar}

Bir İslâm devletinin meşru gerekçeler olmaksızın İslâm devletlerine savaş açması meşru olmayacaktır. Bununla birlikte, tarih boyunca fikhın ilkeleri bağlamında meşruiyet taşımayan sebeplere dayalı olarak Müslümanlar arasında birçok savaş vuku bulmuştur. Müslümanların birbirleri ile savaş yapmasını meşru kilmayan başlıca sebepler olarak, mezhep taassubu ve mezhebi yayma faaliyetleri, zenginlikleri sömürüp hükümranlık alanını genişletmek ve emperyalist güçlerin amaçlarına hizmet etmek sayılabilir.

\section{1-Mezhep Taassubu ve Mezhep Yayma Faaliyetleri}

Hz. Peygamber'in vefatından sonraki süreçte Müslümanlar arasında yaşanılan savaşlar ve çatışmalar, ilerleyen süreçte Müslümanlar arasında onarılması zor yaralar açmıs ve sünnî-şî̀ ayırımının ilk nüvesi olmuştur. İslâm tarihi boyunca olduğu gibi günümüzde de sünnî- şî̀ ayırımı İslâm devletleri arasındaki ihtilafın zeminini oluşturmaktadır. Buna ilave olarak mezheplerin kendi içindeki farklılıklara dayalı olarak da anlaşmazlık ve çatışma gündeme gelebilmektedir.

Mezhep, aynı dine mensup insanların alt kimliklerini ifade etmektedir. İctihad seviyesinde olmayan bir Müslümanın dinî bilgiye bir mezhebi taklid ederek ulaşması ve ona tâbi olarak ibadet ve muamelatını düzenlemesi tabiîdir. Bu amaçla bir mezhebe mensup olmakta bir sakınca bulunmamaktadır. Bir mezhebe mensubiyet demek, kendi mezhebinin doğru ve hakikate ulaştı̆̆ını, diğerlerinin ise hatalı olduğunu düşünmek demektir. Yanlış olan husus, mezhebe mensubiyet değil, mezhebe tâbi olmada bağnazlık ve taassup göstermektir. Mezhep mensubiyetinin taassup boyutu, doğrunun tek temsilcisi olarak kendi mezhebini görmek, kendi yanlşslarını hiçbir zaman görmeye yaklaşmamak, diğer mezheplerin tüm görüşlerini yanlış ve tehlikeli görüp farklı mezhep mensuplarını potansiyel düşman olarak görmektir. 
Mezhep farklllığını meşru savaş sebebi olarak görmek, mezhep taassubunun ve mezhebi din olarak benimsemenin bir sonucudur. Mezhepler dinin anlaşılma çabasından doğan beşerî oluşumlardır. Mezhepleri fert ve toplumların ihtiyaçlarından doğmuş sosyal bir vakıa olarak görmek gerekir. Hiçbir mezhebin İslâm ile aynîleştirilmemesi gerektiğinin bilinmesi gerekir. Bir mezhebe mensubiyet bağlantısı, alt kimlik seviyesini aşıp kişinin kendisini tanımladığı üst kimlik olarak görülmeye başlandığında o mezhebe mensubiyet fikhî açıdan problemli hale gelmektedir.

Belirli bir mezhebi benimseyen bir devletin kendi mezhebinin görüşünü anlatması ve farklı mezhepte olanlara karşı kendi mezhebini savunması tabiî görülebilir. Ancak bunun ötesine geçerek farklı mezhepte olanları öldürmenin, iktidarlarını ortadan kaldırmak amacıyla silahlı mücadeleye girişmenin meşruiyeti bulunmamaktadır. Daha açık ifade ile sünniîliği savunma bahanesi ile hükümeti şî̂ olan bir devlete saldırı meşru olmadığı gibi, şîi bir devletin, sünnî ile kâfiri eş değer tutup, sünnî devletlere karşı kumpas kurmaları, ihanet etmeleri ve doğrudan ya da dolaylı yollarla saldırıda bulunmaları meşru olmayacaktır.

Mezhep farklılı̆ıını ayrışmanın ve kutuplaşmanın gerekçesi olarak sunan iki grup bulunmaktadır. Birincisi, cahillikten kaynaklanan taassupla bir mezhebi savunanlardır. İkincisi ise, mezhep farklillğını suiistimal ederek Müslümanların birlikteliğini bozmak isteyen devletler ve uluslararası kuruluşlardır. Mezhep farklıı̆̆ına dayalı çatışmaların önüne geçebilmek için alınabilecek en etkili yöntem mezhep kavramının sağlıklı bir şekilde öğretilmesi ve dış güçlerin tatbik etmek istedikleri planlara karşı uyanık olunmasıdır. Mezhebin nüfuzunun artması ve geniş kitlelere yayılmasının sağlanması amacıyla yapılacak tüm askerî mücadelelerin fukaha tarafindan gayri meşru olarak ilan edilmesi haksız bir savaşın vukuunu önleme bakımından isabetli olacaktır.

İslâm adına hareket ettiğini iddia etmesine rağmen tevil ve yoruma yer bırakmaksızın açıkça küfrü gerektiren inançlara sahip olanlarla hangi ölçüde mücadele edilebileceği cevaplanması gereken bir sorudur. Burada kastedilenler, tüm Müslümanların ittifakıyla görüşleri İslâm ile bağdaştırılamayan gruplardır. İslâm mezhepler tarihinde mensupları sayıca az olmakla birlikte dinin temel değerlerine aykırı yorumlara, tevili mümkün olmayan bâtıni düşüncelere sahip olanlar, kendisinde nübüvvet görevi olduğunu iddia edenler, vahiy aldığını söyleyenler, bir insanda ulûhiyet vasfi kabul edenler mevcut olmuştur. Bu meşrep ve grupları ikiye ayırmak mümkündür. Birinci grup, gizli ve pasif halde kalmayı tercih edip, sahip olduğu inanc1 kendi içinde yaşayan, dünya kamuoyuna çıkmayan ve fikirlerini başkalarına benimsetmeye çalışmayanlardır. İkinci grup ise, aktif mücadele yöntemini benimseyip, Müslümanların genel itikadına aykırı "batıl görüşleri" her firsatta "İslâm’ın görüşü" diye dile getiren, kendisinden olmayan tüm Müslümanları tekfir edenlerdir.

Birinci grup ile mücadele yöntemi, onları itidal seviyesine getirmek için çalışmak olmalıdır. Bu görev yapılırken, ilmî veriler ve şerî deliller sunularak onların ikna edilmesine çaba sarf etmek gerekir. Mücadele sonunda ikna edilmeleri durumunda problem kalkacaktır. İkna olmamaları durumunda, görüşlerini "İslâm" adı altında sunmamaları sağlanabilir ya da o grubun söylem ve düşüncelerinin İslâm'ı temsil etmediği hakkında halkın bilgilenmesi sağlanabilir. Bu bilgilendirme bütün mezheplerin ittifakıyla güçlü bir şekilde yapılması durumunda, bu gruplar aktif bir eylem içinde olmadıkları için Müslüman toplumun inanc1 üzerinde fazla olumsuz etkileri olmayacaktır. Dolayısıyla da cebrî tedbirler uygulamak gerekli olmayacaktır.

İkinci grup ile mücadelede güzel söz, delillerle ikna etme gibi yöntemlere öncelikli olarak başvurmak gerekli olmakla birlikte, toplumun inancına verdikleri zarardan vazgeçmemeleri durumumda cebrî tedbirlere başvurmak söz konusu olabilecektir. Çünkü bu gruptakilerin öncekilerden fark1, sübutu ve delaleti katî naslar üzerinde yaptıkları keyfi yorumları ve geçmişten günümüze tüm ümmetin bâtıl gördügü görüşleri "İslâm" adı altında benimsetmeye çalışmaları, halkın inanç ve temel değerleri hakkında şüphe ve fitneye düşmelerine sebebiyet vermeleridir. Müslüman toplumun inanç değerleri etrafinda çıkarılan fitnenin söndürülmesi ve ortaya çıkabilecek fesada engel olunması zarurî maslahatlardan olan dinin muhafazası kapsamında olacağı için bu gruplarla gerekli mücadeleyi yapmak âlim ve âmirlerin sorumlulukları arasındadır. Bu mücadeleyi âlimler sözlü irşatları ile âmirler ise verecekleri kararlarla yapacaktır. Bu kararlar arasında, alınan tüm tedbirlerin sonuçsuz kalıp zorunluluk olması durumunda cezalandırıcı cebrî tedbirlere başvurmak da bulunabilecektir.

\section{2-Zenginlikleri sömürmek ve Hükümranlık Alanını Genişletmek}

İnsanlar arasında olduğu gibi toplumlar arasında da hâkimiyet mücadelesi yapmak, başkasının zenginliklerini ele geçirmek ve hükümranlık alanını genişletip tüm milletlere üstün gelmeye çalısmak tarih boyunca hep var olan bir olgudur. Bu ve benzeri gayeler, İslâm devletleri arasında yapilacak bir savaşın meşruiyet sebebi olamayacaktır. İslâm hukukunda mülkiyet hakkı zarûriyyat-1 diniyye kapsamında 
korunması gereken temel değerlerdendir. Bir ferdin sahip olduğu zenginliği sömürmek meşru olmadığ1 gibi, devletlere ait olan zenginlikleri sömürmek de caiz değildir. Müslümanların birbirleri ile kardeşlik hukukuna göre davranmaları emredilmiş ve birbirlerine zulmetleri yasaklanmıştır (Müslim, Birr ve’s-sıla: 6743; Buhârî, Mezâlim: 2310 ). Hz. Peygamber (s.a.) Müslümanı dilinden ve elinden diğer Müslümanların güvende olduğu kimse diye tanımlamıştır (Nesâ̂̂, Siyer: 8701). Dolayısıyla bir İslâm devletinin, başka bir İslâm devletindeki zenginliklere göz koyarak onları ele geçirme amacıyla savaş ilan etmesi meşru olmayacaktır.

Allah Teâlâ, her bir topluluğa farklı farklı nimetler vermiş, bir kısmını zengin, bir kısmını fakir kılmıştır. "Bilmediler mi ki, Allah rızkı dilediğine bol bol verir ve (dilediğine) kısar. Şüphesiz bunda inanan bir toplum için elbette ibretler vardır.” (Kur’an-1 Kerim 39: 52). Bugün zengin olanın yarın fakir, dün fakir olanın bugün zengin olması dünya hayatının bir özelliğidir. “...Işste (iyi veya kötü) günleri insanlar arasında (böyle) döndürür dururuz..." (Kur'an-1 Kerim 3: 140).

Hz. Peygamber'e, gösteriş yapmak, kahramanlı̆̆ını göstermek veya asabiyet duygusuyla kavmini yüceltmek için savaşanlardan hangisinin Allah yolunda olduğunun sorulması üzerine “Allah'ın kelimesinin (hükmünün) en yüce olması için savaşanlar” (Tirmizî, Fedâilu' 1-Cihad: 1646) diye cevap vermesi sırf dünyevî gelir ve hükümranlık gayesi ile savaş yapmanın gayri meşru olduğunu göstermektedir. Gayrimüslimlerle yapılan savaşlarda bile sadece ganimet elde etmek için yola çıkanların kınanması (M. Özdemir, 2014, s. 195) ve Allah yolunda olmadıklarının haber verilmesi, Müslümanların birbirleri ile ganimet savaşı yapmalarının mutlak şekilde yasak olduğunu gösterir. Savaş, gerekli olduğu durumlarda “ Saldırıya karşı savunma ve Allah'ın kelimesinin (hükmünün) en yüce olması amaciyla” yapılır. Bu amac1 taşımayan, dünyevî menfaat gayesi taşıyan, nefsanî arzuların şekillendirdiği tüm savaş planları gayri meşrudur. Savaş kararı alan komuta merkezinden savaşa iştirak eden fertlere kadar herkes bu suçun vebalini taşıyacaktır. Bu sebeple, herhangi bir İslâm devletinin, dĭger İslâm devletinin yeraltı ve yerüstü zenginliklerini ele geçirmek, tarihî ve kültürel değerlerine sahip olmak, hükümranlık alanını genişletmek, savaş sonrası imar faaliyetlerine katılabilmek gibi gayelerle savaş açması gayri meşru olacaktır.

\section{3-Sömürgeci Güçlerin Amaçlarına Hizmet Etmek}

Sömürge durumunda olan ülkeler, ekonomik gelirlerine el konulan, siyasî kararlarında dış güçlerin söz sahibi olduğu, başka devletler tarafından doğrudan ya da dolaylı olarak yönetilen ülkelerdir. (Seyyar, 2007: 955) Sömürgeci ve emperyalist güçler, hedeflerine ulaşmak için her yolu kullanabilmektedirler. Etki altına alıp yönlendirebildikleri devletleri kendi emelleri doğrultusunda kullanabilmekte, savaş dâhil olmak üzere başka devletlere karşı düşmanca davranmalarını sağlayabilmektedirler.

Müslümanların gayrimüslimlerle ilişkilerinde onları dost ve veli edinme yasağı ayetlerde beyan edilmiştir. "Müminleri bırakıp da kâfirleri dost edinenler, onların yanında izzet (güç ve şeref) mi arıyorlar? Bilsinler ki, bütün izzet yalnızca Allah'a aittir." (Kur'an-1 Kerim 4: 139). "Ey iman edenler! Yahudileri ve Hristiyanları dost edinmeyin. Zira onlar birbirinin dostudurlar (birbirinin tarafını tutarlar). İçinizden onları dost tutanlar, onlardandır. Şüphesiz Allah, zalimler topluluğuna yol göstermez." (Kur’ an-1 Kerim 5: 51). Ayetlerden çıkan sonuca göre; bir İslâm devletinin, gayrimüslimleri dost ve veli edinip, onların yönlendirmesi ile Müslüman toplumlara savaş açması hiçbir şekilde meşru olmayacaktır.

Ekonomik ve askerî bakımından güçlü devletler, bizzat savaştığında vereceği can kayıplarını ve uluslararası ilişkilerde uğrayacağ1 itibar kaybını düşünerek "piyon devletler" kullanarak saldırmak istediği yerleri ele geçirme taktiğine başvurabilmektedirler. Bir İslâm devletinin böyle bir planda yer almay1 kabullenmesi hiçbir şekilde meşru olmayacaktır. Her devletin dış politikasını kendi alacağı kararlarla tespit etmesi beklenir. Başka devletlerin arzularına göre diş politikayı belirlemenin sebebi, ya karşılaştı̆̆ı tehdit ve yaptırımlardır ya da güçlü devletin yanında yer alıp menfaat elde etme çabasıdır. Her iki gerekçe de din kardeşine karşı savaşmak için meşru bir sebep olarak gösterilemez. Şahsî menfaat ve küçük çıkar hesaplarıyla güçlü gayrimüslim devletlerin yanında yer alıp onların isteklerine uygun hareket etmenin caiz olmayacağ1 açıktır. Karşılaştığ1 tehdit sebebiyle Müslümanlara savaş açmak da haklı bir gerekçe olarak görülemez. Çünkü zaruretlerin haramları mubah k1lacağ1 fikhî ilke olarak kabul edilmekle birlikte, (İbn Nüceym, 1983, s. 94) hiçbir zaruret durumunun mubah kılmayacağı haramlar vardır. Örnek olarak, tehdit altındaki kişinin haksız yere bir kişiyi öldürmesi caiz değildir (Atar, 1992, s. 132). Buna göre bir devletin kendisine yapılan tehdidi ileri sürerek başka bir İslâm devletine saldırması meşru olmayacaktır. 


\section{Sonuç ve Öneriler}

Mezheplerin teşekkül edip temel fikıh kitaplarının telif edildiği dönemde insanların birbirleri ile münasebetlerinde uymaları gereken konular derinlemesine ele alındığ gibi devletlerarası münasebetler hakkında, özellikle de savaş hukuku alanında kıymetli çalısmalar yapılmışırı. Müstakil olarak yazılan eserlerin yanında fikıh kitaplarında "siyer" başlığı altında darülislâm ile darülharp arasındaki münasebetler ve savaş esnasında uyulması gereken kurallar batı dünyasından yüzyıllar öncesinde ele alınmıştır. İslâm devletlerinin birbirleri ile savaşmaları tabiî ve yaygın bir durum olmadığı için fikıh kitapları savaş konularını genellikle Müslüman olanlar ile olmayanlar arasındaki savaş ekseninde işlemiştir.

İslâm devletlerinin birbirleri ile kardeşlik hukukuna uygun hareket etmesi beklendiğinden savaş ancak arızî ve özel şartların bulunması durumunda meşru olabilecektir. Şahısların kendisini koruması nefsi müdafaa kapsamında meşru olduğu gibi devletlerin de vatandaşlarını ve ülkenin sınırlarını her türlü saldırıya karşı koruması meşrudur. Bu saldırı başka bir İslâm devletinden gelmesi durumunda saldırıya uğrayan devletin nefsi müdafaa hakkı çerçevesinde o devlete karşı savaş yapması meşru olacaktır. Saldırının açıktan yapılmayıp devlet destekli terör faaliyeti şeklinde yapılması halinde de gerekli savunma yöntemleri ile karşllk vermek devletin hem hakkı hem de vazifesidir.

Bir İslâm devletinin dünyadaki zulme ve haksızlı̆̆a kayıtsız kalması doğru olmayacağı için haksız saldırı altındaki Müslüman toplumların yanında yer alması gerekir. Saldıran devletin, sulh girişimlerine olumlu cevap vermemesi ve yapılan uyarlları dikkate almaması durumunda mazlum devletin yanında haksız saldırı bertaraf edilinceye kadar savaşılması gerekir.

Dünyadaki sömürgeci ve emperyalist güçler bazen doğrudan saldırmak yerine başka bir devleti piyon olarak kullanmayı tercih edebilmektedirler. Bir İslâm devleti yönetiminin, güçlü devletlerin çıarları doğrultusunda ve ümmet birlikteliğine zarar verici nitelikte fitne ve fesat içeren politikalar takip etmesi durumunda onunla İslâm ümmetinin çıkarları adına mücadele etmek meşru olacaktır. Bu politikaları benimseyen yöneticilere karşı uyarı ve mücadele etme görevi o devletin kendi vatandaşlarına ait olmakla beraber, izlenen politikalar uluslararası ilişkileri etkileyen boyut kazanması, diğer İslâm devletlerine ve İslâm ümmetinin geneline zarar verici nitelikte olması durumunda onunla mücadele meşru olacaktır. $\mathrm{Bu}$ mücadelede tavsiye, uyarı, tehdit, yaptırım gibi yöntemlerin faydalı olmaması durumunda caydırıcı askerî tedbirlere başvurmak da mümkün olabilecektir.

Bir İslâm devletinin diğer bir İslâm devleti ile savaşması, sadece kendi devletinin değerlerinin ve mazlum durumunda olan diğer İslâm devletlerinin haklarını koruma, fitne ve fesat çıkarma gayesinde olanlara engel olup ümmetin birlik ve beraberliğini temin etme durumunda meşru olacaktır. Böyle meşru bir gaye taşımaksızın, dünyadaki bütün mezheplerin gücünü kırıp sadece kendi mezhebini yaygınlaştırma, zenginliklere el koyarak maddî çıkar elde etme, devletin nüfuz ve etki alanını genişletme, uluslararası emperyalist ve sömürgeci güçlerin hedeflerine ulaşmalarına yardımcı olma gibi amaçlara ulaşmak için bir İslâm devletinin inanç kardeşi olan Müslüman toplumlarla savaşması hiçbir şekilde meşru olmayacaktır.

\section{Etik Beyan}

"İslâm Devletinin Diğer İslâm Devletiyle Savaşmasının Meşru ve Gayri Meşru Olduğu Durumlar" başlıklı çalışmanın yazım sürecinde bilimsel, etik ve alıntı kurallarına uyulmuş; toplanan veriler üzerinde herhangi bir tahrifat yapılmamış ve bu çalışma herhangi başka bir akademik yayın ortamına değerlendirme için gönderilmemiştir.

\section{Kaynakça}

Altuğ, Y. (1995). Teröriżmin anatomisi. İstanbul: Altın Kitaplar Yayınevi.

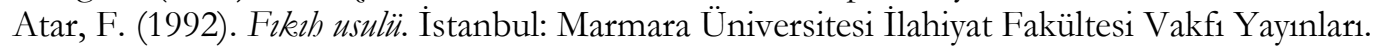

Belik, M.R. (1956). Devletlerin harp salahiyetinin tabdidi ve milletlerarast ibtilaflarn sulh yolu ile halli usulleri. İstanbul: İstanbul Üniversitesi Hukuk Fakültesi Yayınları.

Buhârî, İ. (1993). Sabîbu'l-Bubârî. Beyrut: Daru İbn Kesir.

Doğan, H. (2018). İslâm Hukuku Açısından Müslümanlar ve Müslüman Olmayanlar Arasındaki İlişkinin

Dayandığ1 Esaslar Işı̆̆ıında Savaş-Barış Kavramları. Muhafazakâr Düşünce, 14, 97-118.

Durmuş, Z. (2006). Kur'an-ı Kerim'de ulus ve uluslararası iliskiler. İstanbul: Gökkubbe Yayınları.

Ebû Dâvûd, S. (1987). Sünen-i Ebû Dâvûd tercüme ve șerbi (Çev: N. Yeniel ve H. Kayapınar). İstanbul: Şâmil Yayınevi. 
Graham, E. ve Jeffrey, N. (2007). Uluslararası iliskiler sǫ̈lï̆̈̆̈ (Çev: A. Utku). İstanbul: Gökkubbe Yayınları. Gündüz, A. (1996). Terörle Mücadelede İnsan Haklar ve Güvenlik İkilemi. İstanbul: y.y.

Halîl b. Ahmed, A. (1988). Kitâbü'l-Ayn. Beyrut: Müessetü'l-A'lemi li'l-Matbu.

İbn Kudâme, M. (1992). el-Muğnî. Kahire: Hecr li’t-T1baa ve'n-Neşr.

İbn Kuteybe, A. (1973). Te'villü müşkili'l-Kur'an. Kahire: Darü't-Türas.

İbn Nüceym, Z.(1983). el-Eşbah ve'n-nezâir. Dimaşk: Dâru'l-Fikr.

Müslim, H. (1983). Sabîh-i Müslim Tercüme ve Şerhi. Çev: A. Davudoğlu. İstanbul: Sönmez Neşriyat.

Nesâ̂̀, A. (1981). Sünen'ün-Nesẩ. Çev: A. Muhtar Büyükçınar v.dğr. İstanbul: Kalem Yayınc1lı.

Örgün, F. (2001). Küresel Terör. İstanbul: Okumuş Adam Yayınları.

Özdemir, A. (2014). Hadislerin Rehberliginde Kardeslik Hukuku. Ankara: Murat Kitabevi.

Özdemir, A. (2017). İslâm Hukukunda Uluslararası Kamu Düzeni ve Savaş Hukuku. Ankara: Murat Kitabevi.

Özdemir, M. N. (2014). Hz: Peygamber Döneminde Ganimet Uygulamalar. Ankara: İlahiyat Yayınları.

Özek, A. vdğr. (1993). Kur'an-ı Kerim Açıklamalı Meali. Ankara: Türkiye Diyanet Vakfı Yayınları.

Özel, A. (1981). İslam Hukukunda Ülke Kavramı. İstanbul: İklim Yayınları.

Öztürk, O. (2000). Avrupa ve Orta Doğu Ülkelerinin Terör Karşısındaki Konumları. Teröriżm İncelemeleri,

Ankara: Avrasya Stratejik Araştırmalar Merkezi.

Serahsî, M. (1989). el-Mebsût. Beyrut: Darü'l-Ma'rife.

Seyyar, A. (2007). Insan ve Toplum Bilimleri Terimleri. İstanbul: Değişim Yayınları.

Tirmizî, M. (t.y.) Sünen-i Tirmiẑ̨ Tercümesi. Çev: O. Mollamehmetoğlu. İstanbul: Yunus Emre Yayınevi.

Udeh, A. (1988). Sömürge Hukuku ve İslâm. Çev: Ahmet Davutlugil. İstanbul: İşaret Yayınları.

Ülken, H. Z. (1969). Sosyoloji Sözliuğü. İstanbul: Milli Eğitim Bakanlığı Yayınları.

\section{EXTENDED ABSTRACT}

The relations of the Islamic states in the world with each other should be the establishment of peace, friendship and brotherhood. However, there have been conflicts among the Muslim societies throughout the history with the ignorance of the managers, the incitement of the enemies and the dominance of bigotry. There are four reasons why the Islamic State has fought against another Islamic state: The first of the situations that legitimized war is to protect the borders of the country. The Islamic State has the right to fight against those who are hostile to it and to protect the borders of the country. On the basis of this provision the right to self-defense comes. The right to self-defense has been adopted in international treaties. Another reason why the Islamic State is fighting the war against another Islamic state is: In the event that the decisions of the Islamic state in the direction of the demands of the imperialist powers cause obvious damage to the other states and the common interests of the Islamic Ummah, all kinds of struggle against that state will become legitimate. If an Islamic state serves the interests of international imperialist powers and states and carries threats against other Muslim societies, the struggle against it is justified.

In addition to these reasons, The wars to save those who are under attack are also legitimate wars. Muslims must do their best to stop the oppression. The Qur'an reveals that: "If two parties among the Believers fall into a fight, make ye peace between them: but if one of them transgresses beyond bounds against the other then fight ye (all) against the one that transgresses until it complies with the command of Allah; but if it complies then make peace between them with justice and be fair: for Allah loves those who are fair (and just)." (Hucurat, 49/9). If the attacking state does not respond positively to the peace initiatives and does not take into account the warnings made, it must be fought until the unjust attack is eliminated. The concept of Ummah is the most comprehensive concept that defines Islamic society. Although Muslims are not obliged to organize under a single state in terms of political structure, it is obliged to act with the consciousness of ummah with the responsibility of sharing the same belief.The Qur'an commands Muslims to be together in unity. "And hold fast, all together, by the Rope which Allah (stretches out for you), and be not divided among yourselves; and remember with gratitude Allah's favor on you; for ye were enemies and He joined your hearts in love, so that by His Grace, ye became brethren; and ye were on the brink of the pit of Fire, and He saved you from it. Thus doth Allah make His Signs clear to you that ye may be guided." (Al-i Imran, 3/103). If an Islamic state prevents Muslims from acting together, it would be legitimate to struggle with it. Because this behavior is against the interests of the Islamic Ummah. The main reasons that do not justify the war of Muslims by each other are sectarianism, exploitation of wealth and widening the domain of sovereignty and serving the purposes of imperialist powers. It is wrong to see their sect as the sole representative of the truth, to never see their own mistakes, to see all the views of other denominations as wrong and dangerous and to see different 
sectarian members as potential enemies. To consider sectarian differences as a legitimate cause of war is a result of the adoption of sectarian fanaticism. There is no legitimacy to engage in armed struggle with the aim of eliminating the power of those in different sects. It is not permissible to wage war in order to exploit the riches of an Islamic state.

For this reason, it is illegitimate for any Islamic state to declare war with the intentions of capturing the underground and surface riches of the other Islamic state, having historical and cultural values, and expanding the domain of sovereignty. Each state should determine its foreign policy with its own decisions. The reason for the determination of foreign policy according to the wishes of other states is the threats and sanctions that it encounters, or it is an effort to take advantage of the powerful state. Both reasons cannot be shown as a legitimate reason to fight against the religion brother. In the event that the causes of the war are legitimate, Muslims will make an armed struggle to protect their own state, the Ummah and the oppressed. Although there is no reason to justify war, those who make war will deserve a great punishment in the world and the Hereafter. 